\title{
ANALISIS FAKTOR PRODUKSI USAHATANI CABAI MERAH KERITING (CAPSICUM ANNUM L.) DENGAN MENERAPKAN ATRAKTAN (Suatu Kasus di Kecamatan Pasirwangi Kabupaten Garut)
}

\author{
ANAL YSIS OF PRODUCTION FACTORS TO THE CURLY RED CHILI \\ (CAPSICUM ANNUM L.) FARMING BY APPL YING ATTRACTANS \\ (A Case in Pasirwangi Sub District, Garut Regency)
}

\author{
Tuti Karyani, Sumarno Tedy* \\ Program Studi Ekonomi Pertanian Universitas Padjadjaran, Kampus Jatinangor \\ *Email : marno.tedy@yahoo.com \\ (Diterima 24-08-2020; Disetujui 01-11-2020)
}

\begin{abstract}
ABSTRAK
Cabai merah keriting (Capsicum $s p$ ) merupakan komoditas hortikultura yang dikategorikan sebagai komoditas komersial, kendala utama budidaya cabai merah adalah serangan OPT, salah satu jenis hama yang selalu timbul dan sering merusak tanaman cabai adalah lalat buah ((Bactrocera spp), namun dapat dikendalikan dengan penggunaan atraktan. Pengendalian OPT dengan menggunakan Atraktan diperkirakan dapat menekan biaya produksi dan akhirnya dapat meningkatkan pendapatan petani. Penelitian bertujuan untuk menganalisis faktor produksi terhadap hasil produksi cabai merah keriting dengan dan tanpa menggunakan Atraktan di Kabupaten Garut. Penelitian ini dilaksanakan di Kecamatan Pasirwangi Kabupaten Garut, dengan metode survei pada 72 petani caba merah keriting. Data dianalisis dengan menggunakan analisis fungsi produksi. Hasil Penelitian menunjukkan bahwa bahwa luas lahan, benih, pupuk urea, pupuk $\mathrm{Za}$, pupuk $\mathrm{KCl}$, pupuk NPK, pupuk organik, pestisida dan tenaga kerja secara berpengaruh terhadap produksi cabai merah keriting di Kecamatan Pasirwangi Kabupaten Garut. Penggunaan atraktan berpengaruh terhadap produksi cabai merah keriting.
\end{abstract}

Kata Kunci : Faktor Produksi, Atraktan, Cabai Merah Keriting

\section{ABSTRACT}

Curly red chili (Capsicum sp) is a horticultural commodity that is categorized as a commercial commodity, the main obstacle to red chili cultivation is pest attack, one type of pest that always arises and often destroys chili plants is fruit flies ((Bactrocera spp), but it can be controlled by The use of attractants, pest control using attractants is estimated to reduce production costs and ultimately increase farmers' income. The aim of this study was to analyze the production factors of the production of curly red chilies with and without using attractants in Garut Regency. This research was conducted in Pasirwangi District, Garut Regency, with a survey method on 72 curly red chili farmers. Data were analyzed using production function analysis The results showed that: Land area, seeds, urea fertilizer, Za fertilizer, KCl fertilizer, NPK fertilizer, organic fertilizer, pesticides and labor had an effect on products ii curly red chilies in Pasirwangi District, Garut Regency, the use of attractants affects the production of curly red chilies.

Key Words: Production Factors, of attractant, Curly Red Chili

\section{PENDAHULUAN}

Cabai merah (Capsicum sp)

merupakan salah satu komoditas hortikultura yang dikategorikan sebagai komoditas komersial karena sebagian besar produksinya ditujukan untuk 


\section{ANALISIS FAKTOR PRODUKSI USAHATANI CABAI MERAH KERITING \\ (CAPSICUM annum L.) DENGAN MENERAPKAN ATRAKTAN \\ Tuti Karyani, Sumarno Tedy}

memenuhi permintaan pasar. Karakteristik pengembangannya memungkinkan komoditas tersebut dikonsumsi dalam bentuk segar maupun olahan. Cabai merah juga memiliki banyak kandungan gizi dan vitamin seperti kalori, protein, lemak, karbohidrat, kalsium, vitamin A, B1, dan C (Subagyono, 2010). Pemanfaatan cabai sebagai bumbu masak dibutuhkan setiap saat atau sebagai bahan baku industri makanan, minuman dan obat-obatan, hal ini yang membuat daya tarik untuk pengembangan usaha komoditas cabai.

Sentra produksi cabai di Indonesia terdapat di beberapa propinsi di Jawa dan Luar Jawa. Total kontribusi di beberapa propinsi tersebut sebesar $79,15 \%$ dari total produksi cabai di Indonesia. Berdasarkan rata-rata produksi tahun 2010-2014, Jawa Barat memberikan kontribusi sebesar $22,54 \%$ terhadap total produksi cabai Indonesia, Sumatera Utara $18,15 \%$, Jawa Tengah $14,71 \%$, Jawa Timur 9,66\%, Sumatera Barat 5,62\%, Aceh 4,42\% dan Bengkulu sebesar 4,05\%. (Pusdatin, 2015).

Sentra dan pengembangan tanaman cabai di Provinsi Jawa Barat tersebar di beberapa Kabupaten, antara lain Garut, Cianjur, Bandung, Tasikmalaya, Ciamis, Majalengka, dan Sukabumi. Periode tahun 2011-2016 perkembangan luas tanam cabai di Jawa Barat cukup berfluktuasi tercatat berkisar antara 15.850-17.903 ha. Dari beberapa sentra produksi dan pengembangan cabai di Jawa Barat, Kabupaten Garut merupakan wilayah terluas dibanding kabupaten yang lainnya tahun 2011 seluas 5.031 ha, tahun 2012 seluas 5.125 ha, tahun 2013 seluas 7.217 ha, tahun 2014 seluas 6.476 ha, tahun 2015 seluas 5.625 ha, dan tahun 2016 seluas 6.001 ha.

Berdasarkan Data BPS Tahun 2017 bahwa produksi dan produktivitas Cabai di Jawa Barat ternyata Kabupaten Garut merupakan produsen cabai terbesar dengan produksi tertinggi dicapai pada tahun 2016 sebanyak 80.742 ton, sedangkan produksi terendah tahun 2012 sebanyak 49.591 ton, dengan rata-rata produksi selama 7 tahun terakhir adalah 67.216 ton per tahun.

Kecamatan Pasirwangi merupakan sentra produksi sayuran di Kabupaten Garut, Cabai merah keriting merupakan salah satu komoditas andalan dan hampir sepanjang tahun selalu diusahakan. Berdasarkan informasi dari Dinas Pertanian dan pelaku usahatani bahwa komoditas tersebut telah diusahakan sejak lama. Namun, dalam pengusahaannya masih dilakukan dengan 
sistem semi tradisional terutama dalam pelaksanaan pengelolaan pengendalian hama dan penyakit.

Menurut Meilin (2014), secara umum hama yang terdapat pada tanaman cabai di Indonesia adalah jenis $T$. parvispinus, lalat buah (Bactrocera sp.), kutu kebul (Bemisia tabaci), kutu daun persik (Myzus persicae), kutu daun (Aphididae), dan tungau (Polyphagotarsonemus latus dan Tetranychus sp.). Sementara itu, pengamatan pada lahan pertanaman cabai di Kecamatan Pasirwangi, Kabupaten Garut menemukan beberapa jenis hama yang terdata sebagai hama penting pada tanaman cabai, yaitu: lalat buah, trips, kutu kebul, kutu daun, dan tungau. Dari keempat jenis hama utama tersebut, lalat buah dan trips merupakan jenis serangga hama yang mendominasi karena menimbulkan kerusakan yang cukup serius pada pertanaman di lapangan.

Beberapa jenis lalat buah yaitu Bactrocera latifrons, B. cucurbitae, dan B. papayae teridentifikasi berasosiasi dengan tanaman cabai di Kecamatan Pasirwangi. Lalat buah umumnya menyerang pada fase pembuahan dan menyebabkan kerusakan pada buah cabai yang masih muda maupun buah yang sudah matang (Meilin 2014). Serangan berat umumnya terjadi pada musim hujan, karena bekas tusukan ovipositor serangga betina terkontaminasi oleh cendawan sehingga buah yang terserang menjadi busuk dan jatuh ke tanah (Meilin, 2014).

Usaha pengendalian lalat buah (Bactrocera spp) sudah banyak dilakukan diantaranya menggunakan cara mekanik, kultur teknik, dan hayati. Namun, usaha tersebut belum memberikan hasil yang signifikan karena terdapat banyak kendala diantaranya: serangan lalat buah banyak yang belum disadari, belum tersedia cara pengendalian yang tepat, serta pengendalian yang dilakukan tidak ekonomis. Selain itu, juga dengan menggunakan pestisida kimia yang sangat berlebihan dapat menimbulkan dampak negatif bagi musuh alami hama, lingkungan dan konsumen serta berdampak pada biaya pengendalian menjadi tinggi, sehingga pendapatan petani berkurang (Humaira et al, 2013; Untung, 2007; Ameriana, 2006).

Pengendalian OPT ramah lingkungan akhir-akhir ini menjadi tren dalam pengembangan usahatani cabai dengan tujuan untuk menurunkan penggunaan pestisida sintetis. Pengendalian OPT dengan mempertimbangkan kelestarian 
lingkungan memiliki resiko yang kecil, tidak mengakibatkan hama menjadi kebal serta aman bagi kesehatan manuasia dan lingkungan. Hal ini sesuai dengan UU No. 12/1992, PP No. 6/1995, dan UU No. 13/2010 tentang Hortikultura yang mengisyaratkan bahwa perlindungan tanaman dilakukan sesuai dengan sistem pengendalian hama terpadu (PHT). PHT merupakan salah satu cara pengamanan produksi dari masalah OPT dengan memadukan beberapa cara pengendalian melalui pendekatan yang lebih mengutamakan peran agroekosistem.

Penerapan pengendalian OPT ramah lingkungan pada tanaman cabai memberikan manfaat berupa: (1) peningkatan produktivitas cabai secara berkesinambungan; (2) kelestarian lingkungan; (3) keamanan dan keselamatan petani; dan (4) keamanan konsumen. Indikator kesuksesan penerapan pengendalian OPT ramah lingkungan adalah: (1) keseimbangan ekosistem tetap terjaga; keanekaragaman hayati tetap lestari; (3) residu pestisida minimal; dan (4) biaya produksi dapat ditekan (Haysim, dkk., 2015).

Salah satu usaha pengendalian yang aman bagi lingkungan dan cukup efektif dalam menekan populasi lalat buah adalah penggunaan metil eugenol sebagai atraktan. Metil eugenol merupakan senyawa pemikat serangga terutama lalat buah. Zat ini bersifat mudah menguap dan melepaskan aroma wangi. Metil eugenol dapat diperoleh di pasaran dengan harga terjangkau dan pemakaiannya cukup mudah.

Penggunaan metil eugenol sebagai atraktan lalat buah tidak meninggalkan residu pada buah dan mudah diaplikasikan pada lahan yang luas. Karena bersifat mudah menguap, daya jangkau atau radiusnya cukup jauh, mencapai ratusan bahkan ribuan meter, bergantung pada arah angin. Daya tangkap atraktan bervariasi, bergantung pada lokasi, cuaca, komoditas, dan keadaan buah di lapangan. Beberapa penelitian menunjukkan, penggunaan atraktan metil eugenol dapat menurunkan intensitas serangan lalat buah pada mangga sebesar 39-59\% (Sarwono 2003; Priyono 2004). Atraktan berbahan aktif metil eugenol tergolong food lure, artinya lalat jantan tertarik datang untuk keperluan makan, bukan untuk seksual. Selanjutnya, metil eugenol diproses dalam tubuh lalat jantan untuk menghasilkan feromon seks yang diperlukan saat perkawinan guna menarik 
lalat betina (Nishida dan Fukami 1988; Nishida 1996).

Pengendalian OPT dengan menggunakan Atraktan diperkirakan dapat menekan biaya produksi dan akhirnya dapat meningkatkan pendapatan petani cabai. Di Hawai, pengendalian lalat buah memadukan beberapa teknik pengendalian, antara lain dengan atraktan dalam perangkap, yang dapat menekan penggunaan pestisida kimia sintetis hingga $75-95 \%$ (Vargas 2007).

Keunggulan yang dimiliki atraktan seharusnya teknologi tersebut sudah menyebar dan digunakan secara luas oleh petani. Hal ini dikaitkan dengan kebanyakan petani cabai merah menerapkan biaya produki tinggi dengan harapan hasil produksi tinggi. Padahal perilaku demikian belum tentu menghasilkan hasil yang optimal. Oleh karena itu, petani seharusnya bijaksana dalam penggunaan biaya produksi. Dengan harga cabai yang fluktuatif, usahatani dengan biaya tinggi seringkali menyebabkan kerugian.

Penggunaan Atraktan dalam pengendalian serangan hama lalat buah dapat memberikan solusi sekaligus upaya untuk merubah persepsi petani cabai dalam penggunaan biaya produksi yang tidak terkendali. Penelitian ini berupaya memberikan gambaran faktor-faktor yang berpengaruh dalam produksi cabai merah keriting di Kabupaten Garut melalui analisis faktor-faktor produksi pada usahatani cabai merah yang menerapkan Atraktan dengan yang tidak menerapkan atraktan dalam mengendalikan serangan hama lalat buah.

\section{METODE PENELTIAN}

Penelitian dilaksanakan di Kabupaten Garut, Propinsi Jawa Barat. Penentuan lokasi penelitian ini dipilih dengan pertimbangan bahwa Kabupaten Garut merupakan salah satu sentra produksi cabai di Propinsi Jawa Barat. Kecamatan Pasirwangi merupakan salah satu sentra pengembangan kawasan cabai merah keriting di Kabupaten Garut. Pendekatan dalam penelitian ini didesain secara kuantitatif, dimana penelitian yang mengggunakan metode kuantitatif harus menetapkan spesifikasi model sebagai tahap awal yang harus dikerjakan. Pembuatan model merupakan suatu abstraksi yang sesuai dengan keadaan yang sebenarnya dari faktor yang dianalisis. Pendekatan kuantitatif bertujuan untuk menguji teori, membangun fakta, menunjukkan hubungan antar variabel, memberikan 


\section{ANALISIS FAKTOR PRODUKSI USAHATANI CABAI MERAH KERITING \\ (CAPSICUM annum L.) DENGAN MENERAPKAN ATRAKTAN \\ Tuti Karyani, Sumarno Tedy}

deskripsi statistik, menaksir, dan meramalkan hasilnya.

Desain penelitian yang menggunakan pendekatan kuantitatif harus terstruktur, baku, formal, dan dirancang secara matang. Desain bersifat spesifik dan detail karena merupakan suatu rancangan penelitian yang akan dilaksanakan sebenarnya (Ahmad, 2011). Penelitian ini didesain untuk menganalisis pengaruh penggunaan factor-faktor produksi terhadap produksi digunakan model fungsi Cobb-Douglas, menganalisis faktor yang dominan pengaruhnya terhadap produksi cabai merah keriting digunakan metode analisis regresi dan menganalisis tingkat pendapatan usahatani cabai merah keriting dengan dan tanpa atraktan.

Jenis data yang digunakan dalam penelitian ini adalah jenis data primer dan sekunder. Sumber data primer mencakup seluruh metode pengumpulan data dari sumber asal (original sources) dan dikumpulkan secara khusus untuk tujuan penelitian yang sedang dilakukan. Data primer diperoleh melalui wawancara langsung dengan petani, serta penggalian informasi dari Petugas Penyuluh Lapangan (PPL) setempat. Sedangkan data sekunder diperoleh dari penelusuran pustaka seperti buku, artikel, dan jurnal ilmiah yang relevan dengan topik penelitian ini, serta instansi terkait seperti Badan Pusat Statistik dan Dinas Pertanian Kabupaten Garut dan BPP Kecamatan Pasirwangi.

Untuk mengetahui pengaruh faktor produksi terhadap produksi digunakan model fungsi Cobb-Douglas, model ini dipilih dengan pertimbangan bahwa model fungsi Cobb-Douglas adalah model yang lazim digunakan dalam penelitian ekonomi pertanian karena sifatnya yang praktis dan mudah ditranformasikan ke dalam bentuk linier (Soekartawi, 1994). Bentuk fungsi produksi Cobb-Douglas adalah sebagai berikut:

$$
\begin{array}{ccc}
\mathrm{Y}=\mathrm{a} \mathrm{X}_{1}^{\mathrm{b}_{1}} \mathrm{X}_{2}^{\mathrm{b}_{2}} \mathrm{X}_{3}^{\mathrm{b}_{3}} \ldots \mathrm{X}_{\mathrm{n}}^{\mathrm{b}_{\mathrm{n}}} \mathrm{e}^{\mathrm{u}} \\
\text { Jika } \quad \text { model } \quad \text { tersebut }
\end{array}
$$
ditransformasikan ke dalam bentuk linier, maka formulasi matematisnya akan berbentuk:

Dimana:

$$
\text { Ln } Y=\ln b_{0}+b_{1} \ln X_{1}+b_{2} \ln X_{2}+b_{3} \ln X_{3}+\ldots+b_{n} \ln X_{n}+d_{i}+e
$$

Y : Produksi cabai $(\mathrm{kg})$

$\mathrm{X}_{1}$ : Luas lahan (ha)

$\mathrm{X}_{2} \quad$ : Jumlah benih $(\mathrm{kg})$

$\mathrm{X}_{3} \quad$ : Jumlah pupuk urea $(\mathrm{kg})$

$\mathrm{X}_{4} \quad$ : Jumlah pupuk Za (kg) 
$\mathrm{X}_{5} \quad$ : Jumlah pupuk $\mathrm{KCl}(\mathrm{kg})$

$\mathrm{X}_{6} \quad$ : Jumlsh pupuk NPK $(\mathrm{kg})$

$\mathrm{X}_{7} \quad$ : Jumlah pupuk organic $(\mathrm{kg})$

$\mathrm{X}_{8} \quad$ : Jumlah pestisida (Rp)

$\mathrm{X}_{9} \quad$ : Jumlah tenaga kerja (HKP)

$\mathrm{b}_{0} \quad$ : Intersep

$\mathrm{B}_{\mathrm{i}} \quad$ : Koefisien regresi (parameter yang ditaksir)

E : Kesalahan pengganggu

$\mathrm{D}_{\mathrm{i}} \quad$ : Koefisien dummy

$\mathrm{D}_{1} \quad$ Variabel dummy petani menerapkan atraktan

$\mathrm{D}=1:$ Menerapkan atraktan, $\mathrm{D}=0$ : Tidak menerapkan atraktan

Ketepatan model persamaan diukur dengan koefisien determinasi ganda $\left(\mathrm{R}^{2}\right)$. Suatu penelitian atau observasi perlu dilihat seberapa jauh model yang terbentuk dapat menjelaskan kondisi yang sebenarnya, dengan menggunakan rumus:

$\mathrm{R}^{2}=\frac{\text { Jumlah Kuadrat Regresi }}{\text { Jumlah Kuadrat Total }}$

Apabila nilai koefisien determinasi semakin mendekati 1, maka model semakin baik, karena semakin sedikit keragaman variabel terikat yang dijelaskan oleh variabel lain di luar model.

Untuk mengetahui pengaruh input produksi terhadap produksi secara simultan atau bersama-sama digunakan uji F, dengan persamaan sebagai berikut :

$$
\mathrm{F}_{\text {Hit }}=\frac{\text { Kuadrat Tengah Regresi }}{\text { Kuadrat Tengah Sisa }}
$$

Hipotesis statistik:

- $\mathrm{H}_{\mathrm{o}}: \mathrm{bi}=0$, tidak ada pengaruh faktor produksi) terhadap produksi
- $\mathrm{H}_{1}$ : bi $\neq 0$, terdapat minimal satu faktor produksi berpengaruh terhadap produksi

Dengan ketentuan:

- Jika $F_{\text {hitung }}>F_{\text {tabel }}$ maka faktor produksi berpengaruh nyata terhadap produksi

- Jika $F_{\text {hitung }} \leq F_{\text {tabel }}$ maka faktor produksi berpengaruh tidak nyata dengan produksi.

Uji t digunakan untuk menunjukkan seberapa besar pengaruh satu faktor produksi secara individual dapat menjelaskan variasi produksi dengan hipotesis sebagai berikut:

- $\mathrm{H}_{\mathrm{o}}$ : bi $=0$, faktor produksi berpengaruh tidak nyata terhadap produksi

- $\mathrm{H}_{1}$ : bi $\neq 0$, faktor produksi berpengaruh nyata terhadap produksi

Adapun uji t ditulis dengan rumus:

$\mathrm{t}_{\text {hitung }}=\mathrm{bi} / \mathrm{Sbi}$

Keterangan:

$\mathrm{t}_{\text {hitung }}=$ Uji $\mathrm{t}(\mathrm{t}$-test) 
bi $\quad=$ nilai koefisien regresi

Sbi $=$ standar eror

Dengan ketentuan:

- Jika $t_{\text {hitung }}>t_{\text {tabel }}$ maka faktor produksi secara individu berpengaruh nyata terhadap Produksi.

- Jika $t_{\text {hitung }} \leq t_{\text {tabel }}$ maka faktor produksi secara individu berpengaruh tidak nyata terhadap Produksi.

\section{HASIL DAN PEMBAHASAN}

Untuk melihat pengaruh faktor produksi terhadap hasil produksi cabai merah keriting dengan dan tanpa menggunakan Atraktan di Kabupaten Garut digunakan analisis dengan model produksi Cobb Douglas. Sebelum model regresi dibuat, terlebih dahulu diuji pemenuhan asumsi modelnya. Sukirno (2002) menyatakan bahwa produksi merupakan serangkaian proses dalam penggunaan faktor produksi yang ada untuk menghasilkan barang atau jasa (output). Produksi terkait erat dengan jumlah penggunaan berbagai kombinasi faktor produksi dengan jumlah dan kualitas output yang dihasilkan. Hubungan diantara faktor produksi dan tingkat produksi yang diciptakan dinamakan fungsi produksi.

Faktor-faktor yang diidentifikasi dapat mempengaruhi produksi cabai merah keriting dengan dan tanpa menggunakan atraktan adalah luas lahan. benih, pupuk Urea, Za, pupuk $\mathrm{KCl}$, pupuk NPK, pupuk organik, pestisida, dan tenaga kerja. Usaha untuk memaksimalkan produksi dalam berusahatani yaitu dengan menggunakan faktor produksi secara optimum. Soekartawi (2002) menjelaskan bahwa fungsi produksi adalah hubungan fisik antara masukan produksi (input) dan keluaran produksi (output).

Pengaruh faktor-faktor produksi tersebut terhadap jumlah produksi cabai merah keriting baik pada petani dengan dan tanpa menerapkan atraktan dianalisis menggunakan analisis regresi linear berganda. Analisis ini dimaksudkan untuk menguji seberapa besar pengaruh luas lahan, benih, pupuk Urea, Pupuk Za, pupuk $\mathrm{KCl}$, pupuk NPK, pupuk organik pestisida, dan tenaga kerja terhadap jumlah produksi cabai merah keriting. Hasil analisis regresi linear berganda dapat dilihat pada Tabel 1. 
Tabel 1. Hasil Analisis Regresi Berganda

\begin{tabular}{|c|c|c|c|c|c|}
\hline \multirow[t]{2}{*}{ Variabel bebas } & \multirow[t]{2}{*}{ Ket. Variabel } & \multicolumn{2}{|c|}{$\begin{array}{l}\text { Unstandardized } \\
\text { Coefficients }\end{array}$} & \multirow[t]{2}{*}{$\mathrm{t}$} & \multirow[t]{2}{*}{ Sig. } \\
\hline & & B & Std. Error & & \\
\hline 1. (Constant) & Konstanta & 5.876 & 1.060 & 5.544 & .000 \\
\hline Luas lhn & Luas lhn (ha) $\left(\mathrm{X}_{1}\right)$ & .405 & .061 & 6.637 & .000 \\
\hline Benih & $\operatorname{Jmh}$ bnh $(\mathrm{gr})\left(\mathrm{X}_{2}\right)$ & .123 & .053 & 2.342 & .022 \\
\hline Urea & Jmh urea $(\mathrm{kg})\left(\mathrm{X}_{3}\right)$ & .042 & .061 & 688 & .494 \\
\hline $\mathrm{Za}$ & $\operatorname{Jmh~Za~}(\mathrm{kg})\left(\mathrm{X}_{4}\right)$ & .001 & .055 & .027 & .979 \\
\hline $\mathrm{KCl}$ & $\operatorname{Jmh~} \mathrm{KCl}(\mathrm{kg})\left(\mathrm{X}_{5}\right)$ & .015 & .046 & .315 & .754 \\
\hline NPK & Jmh NPK $(\mathrm{kg})\left(\mathrm{X}_{6}\right)$ & .123 & .042 & 2.932 & .005 \\
\hline Pupuk Organik & Jmh P.Org $(\mathrm{kg})\left(\mathrm{X}_{7}\right)$ & .242 & .062 & 3.924 & .000 \\
\hline Pestisida & Jmh Pes $(\mathrm{kg})\left(\mathrm{X}_{8}\right)$ & -.042 & .076 & -.628 & .532 \\
\hline Tenaga Kerja & $\operatorname{Jmh}$ TK $(\mathrm{kg})\left(\mathrm{X}_{9}\right)$ & .180 & .074 & 2.422 & .018 \\
\hline Dummy Atraktan & Atraktan (menerapkan, tidak) & .069 & .031 & 2.218 & .030 \\
\hline
\end{tabular}

Berdasarkan Tabel 1, maka diperoleh nilai parameter konstanta dan nilai parameter penduga untuk melengkapi model regresi yang sudah dirumuskan sebelumnya. Persamaan regresi linear berganda (model regresi) yang terbentuk adalah sebagai berikut:

Produksi $=5,876+0,405$ luas lahan + 0,123 benih $+0,042$ urea $+0,001 \mathrm{Za}+$ $0,015 \mathrm{KCl}+0,123 \mathrm{NPK}+0.242$ pupuk organik -0.042 pestisida $+0,180$ tenaga kerja +0.069 Dummy Atraktan

Hasil analisis (Tabel 2) memperlihatkan bahwa tidak semua variabel bebas yang dianalisis memberikan pengaruh yang nyata terhadap produksi cabai merah keriting di lokasi penelitian. Hasil analisis faktor produksi pestisida tidak memperlihatkan pengaruh yang nyata terhadap produksi cabai merah keriting dengan nilai koefisien sebesar -0,047. Angka ini mengandung arti bahwa setiap penambahan pestisida sebesar $1 \%$ akan mengurangi produksi sebesar 0,047\%. Hal ini dikatakan secara faktual bahwa penggunaan pestisida sudah intensif sehingga penggunaan pestisida kimia harus sudah mulai dikurangi. Hasil ini sejalan dengan penelitian

Penggunaan pestisida oleh responden petani bertujuan untuk membasmi serangan Organisme Pengganggu Tanaman (OPT). Penggunaan pestisida dalam pengendalian hama dan penyakit harus dilakukan secara selektif atau menggunakan konsep PHT dan menggunakan pesitisida nabati yang dibuat dari sumber daya alam yang 
tersedia di lokasi. diharapkan dapat mempertahankan produksi ketika serangan hama dan penyakit tanaman lainnya menyerang. Namun, penggunaan pestisida sesuai dengan rekomendasi atau aturan-aturan berlaku sehingga tidak mencemari lingkungan. Menurut Hidayah (2014), penggunaan pestisida dalam aktivitas manusia sangat beragam, diantaranya penggunaan pestisida di bidang pertanian yang merupakan salah satu upaya dalam mempertahankan produksi pertanian.

$$
\text { Koefisien determinasi }\left(\mathrm{R}^{2}\right)
$$
menggambarkan seberapa jauh kemampuan model dalam menerangkan variasi varibel terikatnya. Nilai koefisien determinasi yang mendekati satu variabel-variabel bebasnya menjelaskan hampir semua informasi yang dibutuhkan untuk memprediksi variabel terikat. Hasil perhitungan koefisien determinasi penelitian ini dapat terlihat pada Tabel 2 menggambarkan seberapa jauh kemampuan model dalam menerangkan variasi varibel terikatnya. Nilai koefisien determinasi yang mendekati satu variabel-variabel bebasnya menjelaskan hampir semua informasi yang dibutuhkan untuk memprediksi variabel terikat. Hasil perhitungan koefisien determinasi penelitian ini dapat terlihat pada Tabel 2.
Tabel 2. Hasil Koefisien Determinasi

\begin{tabular}{ccrrr}
\hline Model & $\mathrm{R}$ & $\begin{array}{c}\mathrm{R} \\
\text { Square }\end{array}$ & $\begin{array}{c}\text { Adjusted R } \\
\text { Square }\end{array}$ & $\begin{array}{c}\text { Std. Error } \\
\text { of the } \\
\text { Estimate }\end{array}$ \\
\hline 1 & $.986^{\mathrm{a}}$ & .973 & .968 & .09318 \\
\hline
\end{tabular}

Tabel 2, menunjukkan nilai $\mathrm{R}$ Square sebesar 0,973 yang berarti hubungan antara variabel terikat (jumlah produksi cabai merah keriting) dengan variabel bebasnya (luas lahan, benih, pupuk urea, pupuk $\mathrm{Za}$, pupuk $\mathrm{KCl}$, pupuk NPK, pupuk organik, pestisida, tenaga kerja) adalah sangat kuat. Hal ini berarti bahwa hasil produksi dapat dijelaskan oleh faktor-faktor produksi sebesar $97,3 \%$. Sedangkan sisanya $2,7 \%$ diterangkan oleh variabel lain yang tidak tercakup dalam model, yang diduga turut mempengaruhi variasi produksi cabai merah keriting antara lain: iklim, keasaman tanah, kelembaban, dan sanitasi kebun.

Uji F merupakan uji secara simultan untuk mengetahui apakah variabel luas lahan, benih, pupuk urea, pupuk $\mathrm{Za}$, pupuk $\mathrm{KCl}$, pupuk NPK, pupuk organik, pestisida, tenaga kerja, dan tenaga kerja secara simultan mempunyai pengaruh yang signifikan terhadap jumlah produksi cabai merah keriting. Hasil analisis dapat dilihat pada Tabel 3. 
Tabel 3. Hasil Uji Simultan(Uji f)

\begin{tabular}{lrrrrr}
\hline \multicolumn{1}{c}{ Model } & Sum of Squares & \multicolumn{1}{c}{ df } & Mean Square & \multicolumn{1}{c}{ F } & \multicolumn{1}{c}{ Sig. } \\
\hline 1 Regression & 18.733 & 10 & 1.873 & 215.749 & $.000^{\text {a }}$ \\
Residual & .530 & 61 & .009 & & \\
\hline Total & 19.263 & 71 & & & \\
\hline
\end{tabular}

Dari Tabel 3, dapat dilihat nilai $\mathrm{F}$ hitung sebesar 215.749 dengan nilai signifikansi 0,000 . Dengan demikian pvalue $(0,000)<\alpha(0,05)$ maka artinya Ho ditolak dan $\mathrm{H}_{1}$ diterima. Jadi terdapat pengaruh faktor produksi terhadap hasil produksi cabai merah keriting dengan dan tanpa menggunakan Atraktan di Kecamatan Pasirwangi Kabupaten Garut. Penelitian serupa juga dilakukan oleh Diarawati (2011) menunjukkan bahwa secara simultan variabel bebas yang ada dalam model regresi yaitu lahan, benih, pupuk, pestisida dan tenaga kerja berpengaruh signifikan terhadap produksi cabai rawit. Demikian pula dengan penelitian Kusumaningsih (2012), menunjukan bahwa faktor produksi yang berupa luas lahan, tenaga kerja, benih, pupuk kandang, pupuk phonska, insektisida prevaton, dan prekat bonstik secara bersama-sama berpengaruh terhadap produksi kubis.

Uji t dilakukan untuk mengetahui pengaruh variabel bebas (luas lahan, benih, pupuk urea, pupuk $\mathrm{Za}$, pupuk $\mathrm{KCl}$, pupuk NPK, pupuk organik, pestisida, tenaga kerja, dan tenaga kerja) secara parsial terhadap variabel terikat (jumlah produksi cabai merah keriting), dan menganggap variabel lain konstan. Signifikansi tersebut dapat diestimasi dengan membandingkan antara nilai $t_{\text {tabel }}$

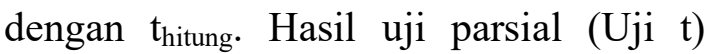
disajikan pada Tabel 4.

Berdasarkan Tabel 4, dapat dilihat pengaruh masing-masing variabel bebas (luas lahan, benih, pupuk Urea, pupuk $\mathrm{Za}$, pupuk $\mathrm{KCl}$, pupuk $\mathrm{NPK}$, pupuk organik, pestisida, dan tenaga kerja) secara parsial terhadap variabel terikatnya (jumlah produksi cabai merah keriting) di Kecamatan Pasirwangi Kabupaten Garut sebagai berikut:

\section{- Luas Lahan}

Hasil pengujian yang dilakukan menunjukkan bahwa faktor luas lahan secara parsial berpengaruh signifikan terhadap jumlah produksi cabai merah keriting di Kecamatan Pasirwangi Kabupaten Garut. Lahan sebagai salah satu faktor produksi yang merupakan pabriknya hasil pertanian yang mempunyai kontribusi yang cukup besar 
terhadap usahatani. Besar kecilnya produksi dari usahatani antara lain dipengaruhi oleh luas sempitnya lahan yang digunakan.

Hal ini berkaitan dengan pengadaan dan manajemen produksi. Misalnya dalam pengadaan pupuk, membeli pupuk satu kwintal mungkin ongkos angkutnya tidak akan jauh berbeda dengan pembelian dua kwintal, sehingga pembelian yang lebih besar relatif lebih efisien dibanding pembelian yang lebih kecil. Begitu juga dalam pengolahan tanah dan pemeliharaan, seperti yang terjadi di lokasi penelitian bahwa ongkos pengolahan tanah dan pemeliharaan 0,14 ha tidak jauh berbeda bahkan mungkin sama dengan luasan 0,21 ha. Dalam manajemen produksi, biasanya petani yang usahanya lebih luas akan berusaha lebih sungguh-sungguh berkaitan dengan modal dan risiko yang lebih besar apabila terjadi kegagalan panen.

Saat ini, rata-rata skala luas lahan yang diusahakan petani cabai merah keriting di Kecamatan Pasirwangi masih di bawah 0,5 ha karena kepemilikan lahan yang terbatas. bila ingin memperluas lahan usahataninya berarti harus mengupayakan dengan cara sewa. Namun terbentur dengan ketersediaan modal, untuk mengantisipasi keadaan tersebut petani harus bisa menjalin kemitraan dengan pihak lembaga permodalan. Produktivitas lahan dapat mempengaruhi besarnya produksi usahatani yang diperoleh petani (Mosher, 1996). Dibandingkan dengan faktor lain, lahan biasanya merupakan faktor yang paling berpengaruh dalam peningkatan produksi.

Tabel 4. Hasil U ji Parsial (Uji t)

\begin{tabular}{|c|c|c|c|c|c|c|}
\hline & \multirow[t]{2}{*}{ Model } & \multicolumn{2}{|c|}{$\begin{array}{c}\text { Unstandardized } \\
\text { Coefficients }\end{array}$} & \multirow{2}{*}{$\begin{array}{l}\text { Standardized } \\
\text { Coefficients } \\
\text { Beta }\end{array}$} & \multirow[t]{2}{*}{$\mathrm{t}$} & \multirow[t]{2}{*}{ Sig } \\
\hline & & B & Std. Error & & & \\
\hline \multirow[t]{11}{*}{1} & (Constant) & 5.876 & 1.060 & & 5.544 & \\
\hline & Luas lahan & .405 & .061 & .356 & 6.637 & .000 \\
\hline & Benih & .123 & .053 & .128 & 2.342 & .022 \\
\hline & Urea & .042 & .061 & .039 & 688 & .494 \\
\hline & $\mathrm{Za}$ & .001 & .055 & .001 & .027 . & .979 \\
\hline & $\mathrm{KCl}$ & .015 & .046 & .011 & .315 & .754 \\
\hline & NPK & .123 & .042 & .130 & 2.932 & .005 \\
\hline & Pupuk Organik & .242 & .062 & .249 & 3.924 & .000 \\
\hline & Pestisida & -.042 & .076 & -.037 & -.628 & .532 \\
\hline & Tenaga Kerja & .180 & .074 & .155 & 2.422 & .018 \\
\hline & Dummy (Atraktan) & .069 & .031 & .066 & 2.218 & .030 \\
\hline
\end{tabular}




\section{- Benih}

Faktor produksi benih menunjukkan berpengaruh secara nyata terhadap hasil produksi cabai. Kondisi di lapangan menunjukkan bahwa benih memang berpengaruh terhadap produksi cabai keriting. Hampir semua petani cabai merah keriting di Kecamatan Pasirwangi menggunakan benih hibrida, umumnya petani menggunakan benih hibrida cabai merah keriting diantaranya magma, bianca. Benih tersebut banyak digunakan petani dengan pertimbangan bahwa benih cabai tersebut sangat adaftif, bisa ditanam di lahan dataran tinggi maupun rendah, produktivitasnya tinggi, ukuran buah relatif seragam, berbiji banyak, rasa pedas dan mempunyai daya simpan yang relatif lama.

Jumlah benih cabai merah yang digunakan baik dengan tanpa atraktan rata-rata per ha sebanyak minimal 200 gr. Anjuran penggunaan benih cabai merah keriting berkisar antara 200-300 gr/ha. Untuk meningkatkan produktivitas cabai merah selain penambahan benih per satuan luas, masih dapat diupayakan pula dengan meningkatkan kualitasnya, dimana benih yang digunakan petani diperoleh dari kios yang sudah dikemas tanpa melihat batas kadaluarsa. Oleh karena itu, peningkatan produksi masih dapat dicapai apabila petani menggunakan benih yang kualitasnya terjamin.

Dalam penelitian ini benih menentukan keunggulan dari suatu komoditas, benih yang unggul cenderung menghasilkan produksi dengan kualitas yang baik. Hasil penelitian ini sejalan dengan hasil penelitian yang dilakukan oleh Sukiyono (2004) yang menunjukkan bahwa bibit berpengaruh secara nyata positif terhadap jumlah produksi cabai. Demikian pula hasil penelitian Herlina (2010) yang menyatakan semakin banyak benih yang digunakan maka produksinya semakin tinggi. Benih yang dimaksud tentu benih yang berkualitas, benih unggul bermutu memiliki daya adaptasi lebih baik, bahkan pada lahan yang kurang produktif sekalipun. Benih unggul bermutu membawa pengaruh besar terhadap peningkatan pendapatan dan kesejahteraan petani.

\section{- Pupuk Urea}

Faktor produksi pupuk Urea menunjukkan pengaruh yang tidak signifikan. Unsur Nitrogen dalam pupuk Urea berperan dalam membuat daun tanaman lebih hijau, dan banyak mengandung butir hijau daun yang mempunyai peranan yang sangat penting 


\section{ANALISIS FAKTOR PRODUKSI USAHATANI CABAI MERAH KERITING \\ (CAPSICUM annum L.) DENGAN MENERAPKAN ATRAKTAN \\ Tuti Karyani, Sumarno Tedy}

dalam proses fotosintesis, mempercepat pertumbuhan tanaman, dan menambah kandungan protein tanaman. Petani di lokasi penelitian umumnya menggunakan dosis pemupukan urea antara $263-296 \mathrm{~kg}$.

Pupuk Urea yang diberikan petani cabai merah di lokasi penelitian sudah berlebih, selain itu pemakaian NPK sebagai salah satu sumber nitrogen juga sudah biasa dilakukan petani dengan dosis antara 491-507 kg/ha. Sehingga kalau dijumlahkan, maka jumlah pupuk sumber unsur Nitrogen sudah cukup tinggi. Apabila pemberian urea terlalu banyak, maka pertumbuhan tanaman akan kurang normal dan rentan terhadap serangan OPT. Salah satu jalan untuk meningkatkan produksi yaitu dengan mengurangi penggunaan pupuk urea. Sujitno (2017) dalam penelitian pengembangan kawasan hortikultura komoditas cabai merah mengemukakan bahwa penggunaan pupuk urea yang berlebihan dan pemberian yang tidak tepat dapat mengakibatkan tanaman cabai menjadi rentan terhadap serangan OPT.

\section{- Pupuk Za}

Pada penelitian ini penggunaan faktor produksi pupuk ZA ternyata tidak menunjukkan pengaruh terhadap produksi yang diperoleh. Melihat jumlah pupuk ZA yang diberikan petani cabai merah keriting di lokasi penelitian berkisar antara 214-239 kg/ha, kegunaan pupuk Za bisa juga sebagai pengganti pupuk urea untuk memasok hara nitrogen. Dosis pupuk Za yang digunakan petani rata-rata lebih rendah dibanding dengan rekomendasi Balai Penelitian Tanaman Sayuran yaitu sebesar 250 $\mathrm{kg} / \mathrm{ha}$. Maka dosis pemberian pupuk ZA di lokasi penelitian mendekati rekomendasi, sehingga penambahan ZA tidak akan meningkatkan produksi secara nyata. Sesesuai dengan rekomendasi dari Balai Penelitian Sayuran tahun 2011 bahwa rekomendasi pupuk ZA dianjurkan agar dosis penggunaan pupuk Za tidak lebih dari $250 \mathrm{~kg} / \mathrm{ha}$. Sejalan dengan pendapat Damanik et al (2011) bahwa penggunaan $\mathrm{Za}$ yang berlebihan tidak selalu dapat meningkatkan produksi.

\section{- Pupuk KCI}

$\mathrm{KCl}$ adalah pupuk anorganik mengandung kalium yang berperan dalam penyusunan protein dan karbohidrat (Prananta, 2001). Berdasarkan hasil analisis bahwa penggunaan pupuk $\mathrm{KCl}$ tidak menunjukkan pengaruh yang nyata. Umumnya petani cabai merah keriting di lokasi penelitian menggunakan pupuk $\mathrm{KCl}$ dengan dosis antara 89-94 kg/ha. 
Dosis tersebut masih dibawah rekomendasi dari Balai Penelitian Sayuran yaitu sebanyak $270 \mathrm{~kg} / \mathrm{ha}$. Menurut pengakuan petani di lokasi penelitian bahwa pemberian $\mathrm{KCl}$ dengan dosis di bawah rekomendasi produksinya sama dengan dosis yang dianjurkan. Pengurangan dosis di bawah rekomendasi beralasan karena sebagian besar petani cabai merah disamping menggunakan pupuk $\mathrm{KCl}$ secara tunggal, juga diberikan berupa pupuk majemuk NPK. Sehingga kekurangan unsur $\mathrm{K}$ dapat dipenuhi oleh NPK tersebut. Saptana (2011) juga menjelaskan bahwa penggunaan pupuk anorganik tidak berpengaruh terhadap peningkatan produksi.

\section{- Pupuk NPK}

Pupuk NPK merupakan pupuk majemuk yang mengandung unsur $\mathrm{Ca}$, $\mathrm{Mg}$, S dan unsur mikro $\mathrm{Zn}, \mathrm{Br}$, Mo. Ketersediaan unsur tersebut akan memacu tanaman tumbuh cepat dan berproduksi secara optimal. Hasil analisis menunjukkan bahwa NPK menunjukkan pengaruh yang cukup nyata. Penggunaan pupuk NPK di lapangan yang dilakukan oleh petani responden di Kecamatan Pasirwangi cukup berpengaruh terhadap produksi cabai merah keriting karena dapat mempercepat pertumbuhan tanaman dan menjadikan tanaman lebih sehat dan kuat, juga dalam aplikasi pemberian pupuk lebih praktis, hemat biaya, hemat waktu dan dosis lebih terukur dan efektif, dengan menggunakan pupuk NPK berarti sudah sekaligus mencakup pemberian unsur hara makro, mikro.

Menurut Saribun (2008), penggunaan pupuk NPK diharapkan dapat memberikan kemudahan dalam pengaplikasian dilapangan dan dapat meningkatkan kandungan unsur hara yang dibutuhkan di dalam tanah serta dapat dimanfaatkan langsung oleh tanaman. Sejalan dengan pendapat Sutedjo (2002) bahwa pemberian pupuk anorganik ke dalam tanah dengan tepat dapat menambah ketersediaan hara yang cepat bagi tanaman. Unsur-unsur dalam pupuk NPK diharapkan akan mudah di serap oleh akar tanaman dan akan mampu memenuhi kebutuhan nutrisi tanaman dibudidayakan sehingga produksi tanaman cabai meningkat.

Dosis pupuk NPK yang digunakan petani cabai merah di lokasi penelitian berkisar antara $491-507 \mathrm{~kg} / \mathrm{ha}$, sementara rekomendasi dari Balai Penelitian Balitsa antara 250-270 kg/ha. Tingginya penggunaan NPK oleh petani karena aplikasi penggunaan NPK dilakukan dengan sistem kocor, dan pemberian 


\section{ANALISIS FAKTOR PRODUKSI USAHATANI CABAI MERAH KERITING \\ (CAPSICUM annum L.) DENGAN MENERAPKAN ATRAKTAN \\ Tuti Karyani, Sumarno Tedy}

pupuk NPK dengan sistem kocor dilakukan sejak tanaman cabai berumur 14 hari, interval waktu pengocoran setiap 10 hari sekali, lamanya pengocoran sampai tanaman panen.

\section{- Pupuk Organik}

Pupuk Organik mempunyai pengaruh yang nyata terhadap peningkatan produksi cabai merah keriting. (Karama dkk, 1995), mengatakan bahwa pemberian pupuk organik selain menambah unsur hara juga akan memperbaiki sifat fisik serta menjaga kestabilan suhu di dalam tanah yang akan meningkatkan kemampuan tanaman dalam menyerap unsur hara yang tersedia. Dari hasil analisis dalam proses produksi penambahan pupuk organik pada usahatani cabai merah keriting di lokasi penelitian dapat meningkatkan produksi secara nyata.

Pada saat ini penggunaan pupuk organik oleh petani di lokasi penelitian dosisnya baru berkisar antara 13,20-15,07 ton/ha, bila dibandingkan dengan dosis rekomendasi hasil penelitian dosis tersebut masih kurang yaitu berkisar 20 ton/ha, dengan demikian penambahan dosis pupuk organik mutlak diperlukan.

\section{- Pestisida}

Berdasarkan hasil analisis bahwa faktor produksi pestisida tidak memperlihatkan pengaruh terhadap produksi cabai merah keriting. Kejadian ini terbukti karena secara faktual bahwa penggunaan pestisida di lokasi penelitian sudah intensif dengan dosis yang berlebih sehingga penggunaan pestisida terutama pestisida kimia harus sudah mulai dikurangi. Kemudian dalam pelaksanaan tindakan pengendalian OPT rata-rata petani tidak memperhitungkan ambang batas serangan, melainkan mereka melakukan pengendalian secara terjadwal dengan setiap aplikasi menggunakan berbagai macam jenis pestisida diberikan sekaligus.

Anggapan petani bahwa menggunakan pestisida secara campuran dapat mengendalikan serangan OPT lebih ampuh, padahal penggunaan pestisida yang tidak tepat dapat menimbulkan masalah kesehatan, pencemaran lingkungan, dan gangguan keseimbangan ekologis. Hasil penelitian Harsanti (2007) menyebutkan bahwa residu pestisida pada tanah dan air berkorelasi positif dengan residu pestisida dalam produk. Selain itu, pada penelitian Hidayat et al (2013) menjelaskan bahwa tingkat pengetahuan petani terhadap pengelolaan pestisida sesuai dengan prinsip kehatihatian masih rendah dan ketergantungan terhadap pestisida masih tinggi. 


\section{- Tenaga Kerja}

Hasil analisis memperlihatkan bahwa jumlah tenaga kerja berpengaruh terhadap produksi cabai di lokasi penelitian. Hasil tersebut mengindikasikan bahwa penambahan jumlah tenaga kerja memberikan pengaruh nyata terhadap kenaikan jumlah produksi cabai merah keriting. Dalam usahatani cabai merah terutama yang berkaitan dengan proses produksi khususnya pada budidaya dari awal sampai akhir yaitu mulai dari persiapan sampai pada pelaksanaan panen dan pasca panen tidak lepas dari kebutuhan tenaga kerja. Dengan kata lain jumlah dan kualitas tenaga kerja dapat menentukan tingkat keberhasilan usahatani cabai.

Hasil penelitian ini sejalan dengan pendapat Pranata dan Damayanti (2016) yang menyatakan bahwa tenaga kerja berpengaruh nyata terhadap produksi cabai merah keriting di Kabupaten Sigi. Umumnya tenaga kerja yang digunakan dalam usahatani cabai merah keriting berasal dari tenaga kerja keluarga (anggota keluarga) dan tenaga kerja luar keluarga. Ketersediaan tenaga kerja yang digunakan sangat berkaitan erat dengan luas lahan yang diusahakan. Biasanya lebih banyak tersedia tenaga kerja maka luas lahan yang digarap pun akan lebih luas. Rata-rata kepemilikan lahan yang digunakan oleh petani untuk usahatani cabai merah keriting di lokasi penelitian kebanyakan di bawah 0,5 ha.

\section{- Dummy (Menerapkan Atraktan dan Tidak Menerapkan)}

Berdasarkan hasil analisis antara petani yang menerapkan atraktan dan petani yang tidak menerapkan atraktan berpengaruh terhadap produksi cabai merah keriting. Hasil survei di lokasi penelitian penggunaan Atraktan pada pengendalian lalat buah mampu menekan biaya penggunaan pestisida sintetis atau petani yang menerapkan pengendalian lalat buah dengan atraktan menghemat biaya produksi. Pengurangan biaya pembelian pestisida sebesar itu disebabkan karena biaya untuk pembelian atraktan jauh lebih murah dibanding dengan menggunakan pestisida sintetis.

Umumnya apabila petani sudah menggunakan atraktan biasanya interval penyemprotan lebih jarang dibanding dengan yang menggunakan pestisida sintetis secara total. Menurut Kardinan (2011), dengan memanfaatkan Atraktan untuk mengendalikan hama lalat buah, penggunaan insektisida sintetis dapat ditekan hingga $62 \%$, kerusakan buahbuahan dapat menurun hingga $35 \%$, dan 
pendapatan petani meningkat hingga $73 \%$.

\section{KESIMPULAN DAN SARAN}

Faktor produksi luas lahan, benih, pupuk urea, pupuk $\mathrm{Za}$, pupuk $\mathrm{KCl}$, pupuk NPK, pupuk organik, pestisida dan tenaga kerja secara bersama-sama berpengaruh terhadap produksi cabai merah keriting di Kecamatan Pasirwangi Kabupaten Garut baik petani yang menggunakan atraktan ataupun yang tidak.

Secara parsial faktor produksi luas lahan, benih, pupuk NPK, pupuk organik, tenaga kerja dan penggunaan atraktan berpengaruh terhadap produksi cabai merah keriting, sedangkan faktor produksi pupuk urea, pupuk Za, Pupuk $\mathrm{KCl}$ dan Pestisida tidak berpengaruh terhadap produksi cabai merah keriting di Kecamatan Pasirwangi Kabupaten Garut.

Teknologi pengendalian lalat buah dengan atraktan, mudah dilakukan petani, dan bisa menggunakan bahan yang tersedia, dengan biaya yang relatif murah dengan hasil cukup efektif. Oleh karena itu, penggunaan Atraktan dalam mengendalikan lalat buah layak untuk dikembangkan. Pengendalian lalat buah dengan atraktan sebaiknya dilakukan secara serentak dan terkonsolidasi antara satu kebun dengan kebun yang lainnya, antara kelompok dengan kelompok yang lainnya harus serempak.

\section{DAFTAR PUSTAKA}

Ahmad Tanzeh. (2011). Pengantar Metode Penelitian. Yogyakarta: Teras.

BPS. (2013). Provinsi Jawa Barat dalam 2013. Bandung: Badan Pusat Statistik Provinsi Jawa Barat. - (2015). Provinsi Jawa Barat dalam Angka 2015. Bandung: Badan Pusat Statistik Provinsi Jawa Barat.

- (2016). Provinsi Jawa Barat dalam Angka 2016. Bandung: Badan Pusat Statistik Provinsi Jawa Barat. . (2017). Provinsi Jawa Barat dalam Angka 2017. Bandung: Badan Pusat Statistik Provinsi Jawa Barat.

Diarawati, P. (2011). Skala Ekonomis dan Efisiensi Penggunaan FaktorFaktor Produksi pada Usahatani Cabai Rawit di Desa Sukawati, Kecamatan Sukawati, Kabupaten Gianyar

Dinas Pertanian Kabupaten Garut. (2017). Laporan Tahunan Dinas Pertanian Kabupaten Garut.

Harsanti, E. (2007). Dampak Penggunaan Pestisida Terhadap Kualitas Lingkungan Fisik dan Produk Bawang Merah serta Perilaku Petani dalam Usahatani Bawang Merah [Tesis]. Yogyakarta: Univesitas Gadjah Mada.

Hasyim, A., W. Setiawati. dan R. Murtiningsih. (2014). Perilaku memanggil ngengat betina dan evaluasi respon ngengat jantan terhadap ekstrak kelenjar feromon seks Hlicoverpa armigera Hubn. 
(Lepidoptera: Noctuidae) pada tanaman cabai merah. J. Hort. 23(1): 72-79.

Hasyim, A., W. Setiawati. dan L. Lukman. (2015). Inovasi Teknologi Ramah Lingkungan pada Cabai. Upaya Alternatif Menuju Ekosistem Harmonis.

Herlinda, S., Mayasari. R., Adam, T dan Y. Pujiastuti. (2007). Populasi Dan Serangan Lalat Buah Bactrocera dorsalis (HENDEL) (Diptera: Tephritidae) serta Potensi Parasitoidnya Pada Pertanaman Cabai (Capsicum annuum L.). Seminar Nasional dan Kongres Ilmu Pengetahuan Wilayah Barat, Palembang, 3-5 Juni 2007.

Hidayah. (2014). Analisis Finansial usahatani cabai merah Skala petani di kota samarinda (studi kasus di kelurahan lempake samarinda). Jurnal AGRIFOR, XIII(1): 1-10.

Hidayat, N. I., A. Daud, dan Erniwati I. (2013). Identifikasi Residu Pestisida Klorpifos dan Prenofos Pada Bawang Merah di Pasar Terong dan Lotte Mart Kota Makassar. Universitas Hasanudin, Makassar.

Humaira, Tasik SB, dan Masriatun. (2013). Pelatihan Pembuatan Atraktan Alami Dari Tumbuhan Aromatika Untuk Pengendalian Lalat Buah Bactrocera Sp. Pada Pertanaman Cabai di Kecamatan Sigi Biromaru. Universitas Tadulako Palu.

Kardinan, A. (2011). Penggunaan selasih dalam pengendalian hama lalat buah pada mangga., Jurnal Littri

Karama, A. S. dan A. Rahman. (1995). Optimalisasi Pemanfaatan sumber Daya Lahan Berwawasan Lingkungan Hal 98-12, Dalam Kerja $\backslash$ Penelitian Tanaman Pangan Buku 1. Kebijaksanaan dan Hasil Utama Penelitian. Pusat Penelitian dan Pengembangan Tanaman, Bukit Bangton.

Kusumaningsih.,R.,D. (2012). Analisis Efisiensi Ekonomi Penggunaan Faktor-faktor Produksi pada Usahatani Kubis di Kabupaten Karanganyar. E.Jurnal Agrista.

Meilin, Araz. (2014). Hama dan Penyakit pada Tanaman Cabai Serta Pengendaliannya. Jambi: Balai Pengkajian Teknologi Pertanian Jambi. diakses dari http://jambi.litbang.pertanian.go.id pada tanggal 4 mei 2017

Mosher, A.T. (1996). Menggerakkan dan Membangun Pertanian, Syaratsyarat Mutlak Pembangunan dan Modernisasi. Jakarta: CV. Yasaguna.

Moekasan, T.K., E. Suryaningsih, I. Sulastrini, N. Gunaeni, W. Adiyoga, A. Hendra, M.A. Martono, dan Kasum. (2001). Penelitian penerapan pengendalian hama terpadu (PHT) pada system tanam tumpanggilir bawang merah dan cabai, dan dampaknya. Laporan Penelitian. Balai Penelitian Sayuran.

Nishida, F. (1996). Sequestration of distasteful compounds by some pharmaco-phagous insects. $J$. Chem.

Pranata, A. (2011). Pemberian berbagai macam kompos pada lahan ultisol terhadap pertumbuhan dan produksi jagung manis (Zea mays saccharata Sturt). Skripsi. Fakultas Pertanian Universitas Riau. Pekanbaru

Pranata, G.W. dan L. Damayanti. (2016). Faktor-faktor yang mempengaruhi produksi usahatani cabai merah keriting di Desa Bulupountu Jaya Kecamatan Sigi Biromaru Kabupaten Sigi. J. Agroland.

Pusat Data dan Informasi Pertanian. (2015). Outlook Komoditas 
Pertanian subsector Hortikultura. Cabai.

Sukirno, S. (1996). Pengantar Teori Makroekonomi edisi kedua. Jakarta: PT. Raja Grafindo Utama.

Saptana, A. Daryanto, Heny K. Daryanto, dan Kuntjoro. (2011). Analisis Efisiensi Produksi Komoditas Cabai Merah Besar dan Cabai Merah Keriting di Provinsi Jawa Tengah: Pendekatan Fungsi Produksi Frontier Stokastik. Forum Pascasarjana Vol. 34.

Soekartawi. (1994). Teori Ekonomi Produksi Dengan Pokok Bahasan Analisis Cobb Douglas Edisi 1. Jakarta: Pt Raja Grafindo Persada. . (1995). Analisis Usahatani. Jakarta: Ui Press. (2003). Prinsip Ekonomi Pertanian. Rajawali Press. Jakarta.

Subagyono, K. (2010). Budidaya dan Pasca Panen Cabai Merah Capsicum annum L. Balai Pengkajian Teknologi Pertanian. Jawa Tengah
Sukiyono, K. (2004). Analisa Fungsi Produksi dan Efisiensi Teknik: Aplikasi Fungsi Produksi Frontier Pada Usahatani Cabai di Kecamatan Selupu Rejang, Kabupaten Rejang Lebong.Kabupaten Rejang Lebong

Soejitno, E., Nurawan, A. (2017). Laporan Kegiatan Pengembangan Kawasan Hortikultura Komoditas Cabai Merah di Kabupaten Garut.

Sutedjo, M. (2002). Pupuk dan Cara Pemupukan. Jakarta: PT Rineka Cipta.

Vargas, R.I., Shelly T.E., Leblanc L. And Pinero J.C. (2010). Recent advances in methyl eugenol and cue-lure tecnologies for fruit fly detection monitoring control in Hawaii. Vitam Horm. 